\title{
The
}

\section{Encyclopedia of Philosophy}

Edited by Dr Paul Edwards, City University of New York

The most comprehensive and authoritative philosophy reference work in English

Eight volumes, 4,300 pages, five million words

1,450 signed articles, 500 contributors from 24 countries, international editorial board of 153 scholars

all major articles followed by individual bibliographies

index of 38,000 entries

a vital reference source for sociologists, historians, theologists, mathematiciansprovides useful background reading for students

price $\mathrm{f88}$

Detailed illustrated brochure available from

Collier-Macmillan Limited

(Dept. EP II)

I0 South Audley Street, London WI 
Vol. VIII

No. 2

\section{DEGEMBER 1966 \\ RATIO}

edited by Stephan Körner (Bristol)

ISAAC LEVI

On Potential Surprise

Hector-Neri Castaneda "He": A Study in the Logic of SelfConsciousness

R. M. MARTIN On Theoretical Entities

Robert W. BEARD "The Will to Believe" Revisited

Reviews:

Rush RHeEs: The Philosophy of Wittgenstein (George Pitcher)

A. C. Ewing: The Case for Rationalism against Modern Philosophical Trends

Price 15a.

Annual subscription: 27s. 6d. net

BASIL BLACKWELL . OXFORD

All communications regarding advertising should be addressed to the Advertisement Managers ...

\section{T. G. SCOTT \& SON, LTD.}

1 Clement's Inn Strand

London, W.C.2

Telephone 01-405-4743

Rates and circulation details on request 


\section{THE AUSTRALASIAN JOURNAL} OF PHILOSOPHY

Edited by A. K. S Tout

\section{ARTCLES:}

Hector-Neri Castaneda: Imperatives, oughts and moral oughts.

Maurice Charlesworth: Meaning and use.

D. Z. Phillips: Religion and epistemology: some contemporary confusions.

David Makinson: How meaningful are modal operators?

Kent Wilson: A note on significant contrast arguments.

R. H. Kane: Turing machines and mental reports.

\section{Crmical Noticks:}

J. B. MeGechie on Brian Ellis's Basic concepts

Walter Cerf on W. B. Gallie's Philosophy and Whe historical understanding.

Reviews, Booxs Recerved, Notrs AND News.

Vor. 44 Dscsmark, 1966 No. 3

Published in May, August and December: Annual Subscription fi $2 s$ Sterling (fi to members of the Australasian Assoctation of Philosophy, which you are invited to Joln) A cample copy and other information may be obtained from the Department of Philosophy. Oniversity of Sydney, NSW
THE PHILOSOPHICAL QUARTERLY

Coutents of Volume 17, No. 66, January 1967

I. Experiences: J. M. Hinton

II. Renembering Dreams: Frederick $A$. Siegler

III. Meaning and the Use of Words: D. M. Taylor

IV. One-Valued Logic: C. L. Hamblin

V. The Nature and Classes of Preacriptive Judgments: Amartya K. Sen

VI. Discussion: Family Resemhlance: L. Pompa

VII. Book Reviews

VII. I Ist of Books Received

Edited by G. P. Henderson with the assistance of Roland Hail, and published for the Scots Philasophtical Ciwb by the University of St Andrews.

Price twenty-five shillings per annum (in U.S.A. $\$ 4.00$ ), poat free, for orders placed directly with the Treasurer (Miss J. S. M Allan, The University, St Andrews, Scotland) or the Assistant Treasurer (Prof. V. C. Chappell, Dept. of Philosophy, University of Chappell, Dept. of Philosophy, Univeraity of
Chicago, Chicago 37, Illinois, U.S.A.). For orders placed through booksellers or agents the price is thirty shillinge per annum (in U.S.A. \$5.00).

\section{THE HIBBERT JOURNAL}

rational, liberal, empirical

Edited by H. L. SrorT

Contents of the Spring issue include:

Ethical studies:

Reinhold Niebuhr on ethics, Warren K. A. ThOmpson

Stephenism, Mexriak H. Carre

Is there a limit? G. W. Butrerworth

Moral key-words in translation, H. L. SHORT

The influence of Homer Lane (3), W. DAvio WiLrs

Diary of a Sudanese student (2), Francis M. Deno

Story: Aftermath, JAMrs MAcAlPnns

Poetry, new books, etc.

Annual Subscription, 13s. 6d. post free. Single Copies 3s. 6d. net

A free specimen copy of a back number will be sent on request

GEORGE ALLEN \& UNWIN LIMITED 40 MUSEUM ST. LONDON, WCI 


\title{
Merleau-Ponty's Critique of Reason
}

\author{
BY THOMAS LANGAN
}

When struck down in 1961 at the relatively young age of 52, Maurice Merleau-Ponty had already acquired the reputation of a giant among contemporary philosophers. His brilliant vision and pertinent criticisms of psychology, Marxism, anthropology, language, and the arts continue to evoke enthusiasm, and, more importantly, his work represents a revealing development of deep tendencies in the tradition that flows from Hegel and Marx to Sartre and Heidegger. This study reviews the entire course of Merleau-Ponty's thought, and analyses the difficulties that face such a critical philosophy. 45 s net.

\section{Metaphysics, Reference, and Language \\ BY JAMES W. CORNMAN}

As he investigates new approaches to metaphysical problems, Professor Cornman both uses and criticises the tools of contemporary analysis, comparing traditional solutions to the mind-body problem, his representative issue, with linguistic approaches. His crucial discussion of linguistic reference uncovers the paradox that while non-philosophers have no difficulty in knowing what they are talking about, philosophers find it virtually impossible to discover what the words they use refer to. $56 \mathrm{~s}$ net.

\section{YALE UNIVERSITY PRESS}

70 Great Russell Street London WC1 


\section{INQUIRY}

An Interdisciplinary Journal of Philosophy and the Social Sciences

\section{Edited by ARNE NAESS}

Volume 10 SPRING 1967 Number 1

Inquiry as a Transcendental Activity

A. C. Genova

Empirical Certainty and the Theory of Important Criteria MichanI. ANTHONY SLOTE On Describing Colours Bernard Harruson Can Heidegger be Understood?

RICHARD SCHMTT

Seinsverlassenheit in the Later Philosophy of Heidegger

S. L. BARTKY

Dizcunaions:

Negation and Deontic Assertions

Ropert L. Holmes

On Our Knowledpe of the Social World

Reply to Silvers
ARNOLD LEVison

Review Discuscions:

New Essays on Plato and Aristotle (Ed. Renford Bambrough)

JaAkKo HintikKa

Law and Psychology in Conflict (J. Marshall)

paul K. Feyerabend

Published quarterly by Universitetsforlaget, P.O. Box 307, Blindern, Oslo 3, Norway. Annual anbscription: 35s., 16.00 postage included.

\section{RATIONALIST ANNUAL : 1966}

H. J. EYSENCK

The Place of Indoctrination in a World of Rationalists

ANTONY FLEW

Evolution and Ethics: Four Approaches

ALEX COMFORT

A Technology of the Emotions

Morality $\underset{\text { and Religion: A }}{\text { DERER Weview of }}$

BENJAMIN FARRINGTON

The Humanism of Epicurus

MAURICE GOLDSMITH

The Science of Science

J. $W$. SHEPHERD

Moral Training and Psychology of Learning

H. L. ELVIN

Wells (1866-1966)

Cloth, 7s. 6d. (postage 6d.)

Paper, 5s. (postage 5d.)

BARRIE AND ROCKIIFF

2 Clement's Inn, London, W.C. 2. in association with

PEMBERTON PUBLISHING CO.

\title{
HOWES BOOKSHOP
}

\section{TRINITY STREET • HASTINGS}

Gatalogue 164, sent free on application, contains:

\author{
PHILOSOPHY AND PSYCHOLOGY \\ THEOLOGY AND GHURGH HISTORY \\ GLASSICAL GREEGE AND ROME
}

Scholarly catalogues published thrice yearly

Libraries and Collections purchased 


\section{BERTRAND RUSSELL}

\section{Philosophical Essays}

These essays stand exactly as originally published and the author has made no attempt to modify them to accord with the changes in his opinions which have developed in the interval. . . . a vintage Russell, but as clean and astringent as when first bottled.'

Times Literary Supp/ement.

$30 s$.

SUSHIL KUMAR SAXENA

\section{Studies in the Metaphysics of Bradley}

Shows a remarkable insight into Bradley's intention and way of thinking.

458.

DON LOCKE

Perception and

Our Knowledge of the External World

Discusses the philosophical problems of perception, beginning with an analysis of perception itself.

$42 s$.

Edited by S. RADHAKRISHAN

and P. T. RAJU

The Concept of Man

A STUDY IN COMPARATIVE PHILOSOPHY

Indicates that the disagreements of religion, philosophy and science have generated a new desire to know the nature and destiny of man. Second Edition.

428.

\section{ALICE AMBROSE}

\section{Essays in Analysis}

Essays that range from questions concerning our knowledge of the external world to questions about logical entailment, mathematical proof, and induction.

40s.

\section{GEORGE ALLEN \& UNWIN 40 Museum Street, London WC1}




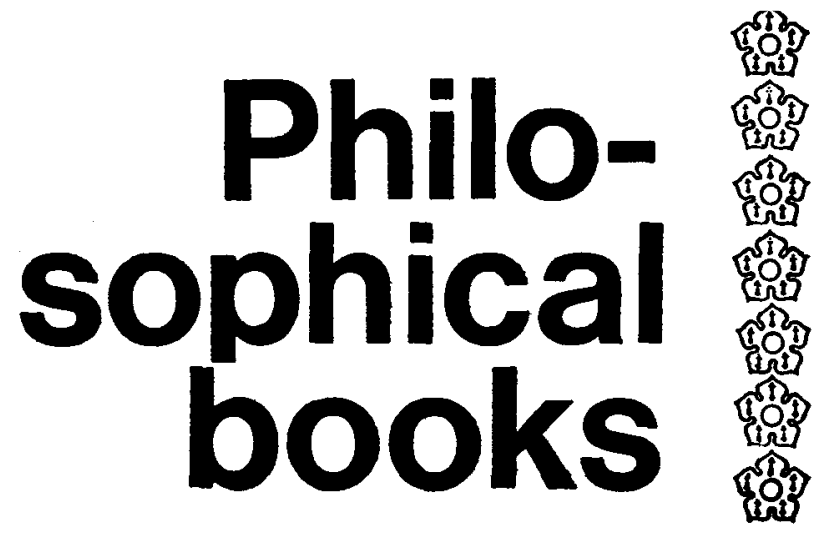

first appeared in January 1960. It is now edited by J. Kemp, Professor of Philosophy in the University of Leicester. The Analysis Committee functions as the editorial board.

is devoted entirely to book reviews; its policy is to print informative notices and assessments of worthwhile new books as soon as possible after their publication. It is published three times a year, in January, May and October. The annual subscription is 14s. (U.S. $\$ 2.00$ ), and single copies cost $5 \mathrm{~s}$. (\$1.00).

Subscriptions and orders for single copies should be sent to the Secretary, Leicester University Press, The University, Leicester, England; or mày be placed through any bookseller.
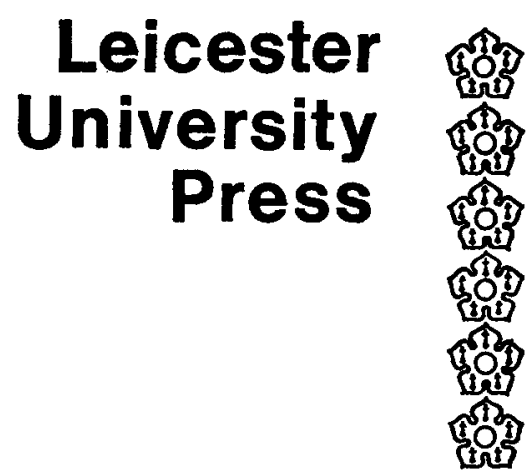


\section{MAN, THE UNIVERSE AND MIND}

\section{P. A. MORITZ}

An inquiry into Perception, Object and World Theory problems 102 pages. Card cover 8s. 6d.; Stiff washable cover 10s. 6d.

Supplementary to which is now available:

DIALECTICAL THINKING IN EMPIRICAL ANALYSIS

by the same author

An exposé of the Consistency Calculus, Truth-Direction and of Insight-Level progressions.

80 pages. Duplicated. Printed card cover. 3s. 6d.

\section{MARTIGAN PUBLICATIONS}

Nethercot Mill, Combe Florey, Taunton, Somerset, England AND OF ALL BOOKSELLERS.

\section{MIND}

\section{April 1967}

I. Husserl versus Frege: E. PIVCEVIC

II. Propositions and Speech Acts: L. R. REINHARDT

III. The Argument from Illusion in Aristotle's Metaphysics ( $\Gamma, 1009-10)$ : A. KENNY

IV. Observation and Reality: D. W. THEOBALD

V. On Avowing Reasons: N. S. CARE

VI. Visual Experiences: J. M. HINTON

VII. Fact and Value: P. T. MACKENZIE

VIII. On Blaming: L. KENNER

IX. An Ethical Paradox: B. COHEN

X. Discussion Notes:

Probability and the Theorem of Confirmation: W. TODD

The Space-Time World: C. W. K. MUNDLE

Evidence for Creation: K. STERN

On Moore's Paradox: D. GOLDSTICK

In Reply to Professor Stephen Körner, on Science and Moral Responsibility: R. HARRE

In Defence of Euclid: A Reply to B. Meltzer: W. H. HALBERSTADT

Third Possibilities and the Law of the Excluded Middle: R. WOOLHOUSE

XI. New Books

A Note on the "Is-Ought" Barrier: M. ZIMMERMAN

XII. Notes

Annual Subscription 25s post free; single copy $756 d$ plus postage

Published for MIND ASSOCIATION by BASIL BLACKWELL, OXFORD 


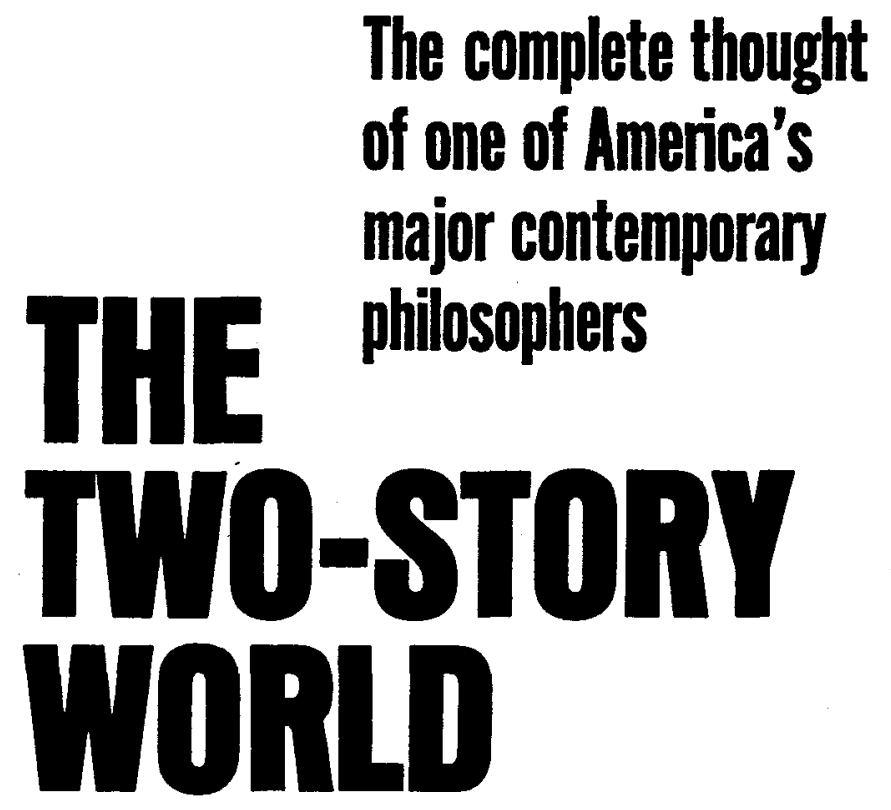

Selected

Writings of

JAMES K.

FEIBLEMAN

"Feibleman is a philosophic synthesizer in the grand manner. This anthology amply bears out the universality of Feibleman's system. Assembled from his voluminous writings of the last 30 years, it includes critical samples of his thought on a vast array of subjects, from morality and religion, through art criticism, to science, history, education, and literary

Edited and

with an

introduction

by HUNTINGTON CAIRNS

$88 \mathrm{~s}$ from your bookseller, or from the publisher criticism. As an introduction to a complex system of thought, this anthology should prove to be extremely useful." - Library Journal

"The work of Feibleman is most impressive for its wide range and for its scholarly insight and critical comment on a great variety of themes and problems." - Journal of the History of Philosophy

(1) Holt, Rinehart and Winston, Ltd

116-120 Golden Lane, The Barbican, London E.C. 1 


\section{ESSAYS IN PHILOSOPHICAL PSYCHOLOGY}

\section{Edited by Donald F. Gustafson}

Twenty essays by leading contemporary philosophers, including Gilbert Ryle, A. J. Ayer, J. L. Austin and P. F. Strawson, bearing on the nature of mind, intellect, will, action, emotion, and the mental processes through which human nature and behaviour must be understood.

25s, Paper 15s.

\section{THE GREDIBILITY OF DIVINE EXISTENGE : THE COLLECTED PAPERS OF NORMAN KEMP SMITH}

\section{Edited by G. E. Davie, R. D. Naclennan and A. J. D. Porteous}

Articles which the author himself considered worthy of preservation in permanent form, ranging from his early articles on Avenarius, Hume, the Middle Ages and the Renaissance, and his lectures and papers on Locke, Bergson and Whitehead, to his logical work on Universals and his views on God, Immortality and Fear.

50 s.

\section{MATERIAL OBJECTS}

\section{W. D. Joske}

The book discusses the interpretation of experiences as experiences of a solipsistic universe, and argues that solipsism does not provide an adequate foundation for rationality.

$30 \mathrm{~s}$.

\section{Reissue}

\section{WHITEHEAD'S PHILOSOPHY OF ORGANISM}

\section{Dorothy Emmet}

Professor Emmet has supplied a new preface calling attention to difficulties she had insufficiently noted and indicating respects in which she would now give a rather different interpretation to some aspects of Whitehead's work.

\section{Two books by Trevor Ling}

\section{BUDDHA, MARX AND GOD}

'This excellent book explores the past and future pattern of BuddhistMarxist relations.'-Ninian Smart, Guardian

\section{PROPHETIC RELIGION}

A strongly emphasised argument pointing out the necessity, for any Christian body, of a fully-balanced religious life and practice. $21 \mathrm{~s}$. 


\section{Back Issues of Journals}

in

\section{THE HUMANITIES AND SCIENCES}

\author{
always required by
}

WM. DAWSON \& SONS Ltd

Back Issues Department,

16 West Street

FARNHAM

Surrey, England

Telephone: 025134664

Cables: Dawbooks Farnham

\section{THE BRITISH JOURNAL} OF AESTHETICS

A Joural for the understanding and appreciation of the arts, and of the principles of eriticisn.

Editor: HaroLd OsborNe

Volume 7, No, 2 April 1967

\section{CONTENTS}

Current Aesthetic Fallacies

Current Aesthetic Fallacies Phiup Honsanum Byzantine Art as a Religious and Didactic Art The Romantic Aesthetics of 1600 P. A. Michelis

WLADYSIW TATARKrewcz Colour-Defective Students in Colleges of Art Colour-Defoctive Students R. W. PICKFORD Symposium: Wittgenstein and Problems of Objectivity in Aesthetics

The Architect as Artíst RetT, Margaret PatoN and HARRY BLOCKRR W. Sinclair Gauldie A note on Objet Trouve SINCLAIR GAULDIE Art and Contemporary Science

Book Reviews.

KeNNETH CouTrs-Smith

Published Quarterly for the British Soctety of Aesthetic: by Thames \& Hudson, Lid, 30 Bloomsbury St., W.C.1. Price $£ 3$ per annum (single issues is/6) from the publishers or through any bookseller. The Journal is supplied free to members of the Society: subscription two guineas per annum. Forms of application from the Hon. Secreiary, clo Department of Philosophy, Bedford College, Regent's Park, London, N.W.1.

\section{Philosophy, Poetry, History}

An Anthology of Essays

BENEDETTO CROCE

Translated and Introduced by

CECIL SPRIGGE

'The selection and arrangement give a really structural grasp of Croce's thought, and the translation is masterly: it is beautifully and limpidly readable.' Kathleen Nott in The Observer 1 plate $£ 55$ net

\section{Wittgenstein's Logical Atomism}

\section{JAMES GRIFFIN}

In this study, now reprinted, of the central philosophical topics of Tractatus LogicoPhilosophicus, the author's aim is to understand Wittgenstein's programme of analysis. 25s net Oxford Classical and Philosophical Monographs

\section{The Meaning of Stoicism}

\section{LUDWIG EDELSTEIN}

In an elegant essay, originally delivered as the Martin Classical Lectures, a great scholar attempts to define Stoicism by grasping the common element in the various schools that have existed since the time of Zeno and his followers. $21 s$ net Harvard University Press

\section{OXFORD UNIVERSITY PRESS}




\section{Treasury of THOUGHT}

\section{by DAGOBERT D. RUNES}

This volume is truly and doubly a "Treasury": With its easy-to-read structure of brief entries in alphabetical order, it is a treasure-house of observations on life and death, civilisation and savagery, the universe and Beyond-the Great Topics which have challenged man's thought, whether in passionate public debate or in the lonely stillness of his nights, ever since he first raised his eyes to the stars. At the same time, this is a "personal treasury" of the intimate thoughts of an outstanding modern philosopher on these Great Topics.

Dr Dagobert D. Runes is the author of over thirty books in the field of philosophy and social history. The late Albert Einstein said that his "... expressed opinions are closely akin to those I hold ..." and who has been saluted by Albert Schweitzer in these words: "We both travel on the same path to bring to mankind a deeply ethical, deeply spiritual consciousness."

PHILOSOPHICAL LIBRARY, INC. 15 East 40th Street, New York 16, N.Y. 


\title{
Philosophy, Politics and Society \\ Third Series
}

Edited by PETER LASLETT and W. G. RUNCIMAN Political philosophy is not being conducted with the range and confidence of the classical theorists. But, as these ten papers show, it has decidedly not abdicated from its proper concern with important issues.

About 35s. net

\section{Religion and Understanding}

\author{
Edited by D. Z. PHILLIPS
}

In these collected papers the editor sees as a common thread the centrality of the concept of understanding in relation to religion, and considers that the analyses their authors give of religious belief go far towards showing what 'true' religion is.

About 35s. net

\section{Wittgenstein und der Wiener Kreis Conversations recorded by $\mathbf{F}$. Waismann Edited by B. F. McGUINESS}

In these conversations with Schlick and Waismann, Wittgenstein expounded views similar to those of Philosophische Bemerkungen, defended some of the doctrines of the Tractatus, while criticising others, and occasionally reacted to the criticisms of his interlocutors. They were recorded in shorthand, and have been transcribed in German for the present edition.

About 35s. net

\section{Ludwig Wittgenstein: A Memoir and Letters}

PAUL ENGELMANN

\section{Translated by L. FURTMULLER}

Engelmann was a friend and disciple of Wittgenstein's at just the time when Wittgenstein was composing his Tractus. He was intensely interested in cultural and (in a wide sense) religious questions; it is from this side that his Memoir illuminates Wittgenstein. There are also about 50 letters of Wittgenstein in German and English.

Reprint

About 35s. net

\section{Being and Time \\ MARTIN HEIDEGGER}

Translated by J. MACQUARRIE and E. ROBINSON A knowledge of Heidegger's Sein und Zeit is essential for anyone who wishes to understand a great deal of recent continental work in theology and philosophy. The translators have succeeded in clothing Heidegger's thought in English without sacrificing the richness and poetic subtlety of the original.

About 63s. net 


\section{The Journal of Philosophy}

A BIWEEKLY journal containing philosophical articles of current interest and encouraging the interchange of ideas. Editors: John H. Randall, Jr., Arthur Danto, Sidney Morgenbesser, Charles D. Parsons, and James J. Walsh. $\$ 7.50$ a year; to students, $\$ 6.00 ; 50$ cents a copy.

Now Avallable: Cumulative Fifty-year Index, 1904-1953; articles classified by subject and author; 452 p., cloth, $\$ 12.00$. Also, Ten-year Supplement, 1954-1963; $\$ 3.00$ cloth, $\$ 2.00$ paperbound. Both Indexes, bound together, $\$ 15.00$.

BACK NUMBERS and volumes: 1960 to 1966 (LVII to LXIII), $50 \mathrm{c}$ /issue, $\$ 12.00$ /volume; 1940 to 1959 (XXXVII to Lvi), $75 \mathrm{c} /$ issue, $\$ 18 /$ volume; 1904 to 1939 (I to XXXVI), \$1/issue, \$24/volume.

720 Philosophy Hall, Columbia University, New York 10027

\section{FOUNDATIONS OF LANGUAGE}

International Journal of Language and Philosophy

Editorial Board: Morris Halle (MIT), Peter Hartmann (Münster/W), K. Kunjunni Raja (Madras), Benson Mates (Univ. of California), J. F. Staal (Amsterdam), Pieter A. Verburg (Groningen), John W. M. Verhaar (Manila).

\section{VOLUME 2 No. 4 NOVEMBER 1966}

Articles: Archibald A. Hill: Non-Grammatical Prerequisites-Anatol Rapoport, Amnon Rapoport, William P. Livant, John Boyd: A Study of Semantic SpaceB. K. Matilal:Indian Theorists on the Nature of the Sentence (vakya). Discussion: On a Misapprehension of the Status of Theories in Linguistics, by Y. Bar-Hillel. Reviews by Martha Kneale, Kurt Rudolf Fischer, James D. McCawley, Peter Sgall, Jacek Fisiak, Fritz Güttinger, and Barbara M. H. Strang.

FOUNDATIONS OF LANGUAGE is published quarterly

Annual subscription price $f 42$. - (\$11.75; 84s.)

D. REIDEL PUBLISHING COMPANY / DORDRECHT-HOLLAND 